\title{
The infinitive in Baltic and Balto-Slavic
}

\author{
Miguel Villanueva Svensson \\ Vilnius University \\ Miguel.Villanueva@flf.vu.lt
}

\begin{abstract}
This article presents a new approach to the Baltic and Balto-Slavic infinitive system. It is argued that the traditional view (which, in essence, derives the Slavic infinitive - $t i$ from PIE loc. sg. * -tēe $i$ and projects all Baltic infinitive endings back into Balto-Slavic) is for several reasons problematic. Balto-Slavic possessed just one infinitive (OCS - $t i$, Lith. $-t i<$ Bl.-Sl. *-ti < PIE dat. sg. *-tei-ei, as per Hill 2016) and a supine (OCS -tz, Lith. -tu< Bl.-Sl. *-tun < PIE acc. sg. *-tum). All other infinitive endings of Baltic (OPr. -twei, Lith. dial. -tie, Latv. refl. -tiê-s) were an exclusive creation of this branch. The reasons for the expansion of the infinitive in Baltic are also discussed.
\end{abstract}

\section{Keywords}

Baltic - Slavic - Indo-European - infinitive - converb

\section{$1 \quad$ Introduction}

It seems almost self-evident that the infinitive ending of OCS $d a-t i$ "give", ves$t i$ "lead" (pres. vedo) must be cognate with its Lithuanian pendant dúo-ti, vès-ti "id." (pres. vedù). The same holds true for the supine OCS da-tz, ves-tz = Lith. dial. dúo-tu, vès-tu. The conclusion to be drawn from these correspondences seems rather straightforward: the (late) Balto-Slavic verb system possessed an infinitive (on whose origin see below $§ 6$ ) and a supine (Bl.-Sl. *-tun $<$ PIE *-tum, cf. Lat. supine-tum).

This pristine picture, however, is immediately compromised by the Baltic evidence, which seems to require several infinitive endings for each of the Baltic languages. OPr. $d \bar{a}-t$, for instance, is compatible with Lith. dúo-ti, but not with OCS da-ti. The Slavic ending is compatible with both Lith. dial. dúo-tie 
and Latv. refl. ves-tiê-s, which apparently differ from each other in intonation. OPr. -twei, finally, has no pendant in either East Baltic or Slavic. The conclusion to be drawn from these facts seems, once again, rather straightforward: (late) Balto-Slavic had several infinitive endings.

It thus seems that two equally reasonable face value analyses of the data point to two mutually exclusive reconstructions of the Balto-Slavic infinitive system. The purpose of this article is to argue that only the first option is correct. I will first present a brief survey of the facts as they have been traditionally understood $(\S 2-4)$. I will then argue that the traditional analysis leads to a paradox and is for several reasons problematic $(\S 5)$. As a way out of the current impasse, I will present alternative accounts of the Baltic infinitive endings $(\S 6-9)$. The picture that emerges is that the morphology of the infinitive experienced a period of expansion in Baltic $(\S 10)$.

The Slavic infinitive (OCS, ORu.) - $t i$ is generally derived from a $t i$-abstract loc. sg. * ${ }^{*}$ tei.. ${ }^{1}$ A less favored option is the dat. sg. * ${ }^{*}$ tei, which in turn would be a haplologized version of (pre-)PIE *-tei-ei (cf. $i$-stem dat. sg. OCS kost-i, Lat. turr-i) ${ }^{2}$

Segmental phonology does of course not allow us to say whether OCS-ticontinues PIE *-tei $i$ or *-tei (or, if this could be justified morphologically, pre-Slavic

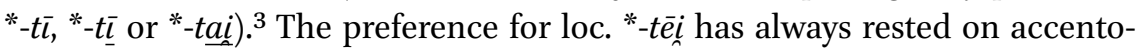
logical arguments, which makes it necessary to discuss accentuation in some detail here.

The traditional argument is that the final accent of Sl. *nesti is due to "Saussure's law" and that, accordingly, it requires a pre-Slavic acute ending *-tī < Bl.-Sl. *-tei $<$ PIE *-tēi. ${ }^{4}$ It cannot be stressed enough that this reasoning rests on a completely obsolete understanding of Balto-Slavic accentology. First (and most importantly), it has been generally accepted since Stang (1957) that Saussure's law was an exclusively Lithuanian phenomenon that did not operate in Slavic at all. Second (and more controversially), the idea that PIE ${ }^{*}$-tēi $i$ gave an

1 This is by far the most widespread opinion (e.g. Stang 1942: 97, Vaillant 1966: 127, Olander 2009: 178, among many others).

2 E.g. Meillet (1934: 242), Matasović (2008: 300), among others.

3 Through this article I note the Balto-Slavic and Proto-Baltic acute as $\underline{\bar{E}}$ (whereas $\overline{\mathrm{E}}$ expresses non-acute or simply length, without specification of acuteness). I have kept the traditional notations for "Proto-Slavic" (in spite of its inadequacy; see Olander 2015: 42-45 for discussion) and Proto-East Baltic ( $(\hat{\mathrm{E}}=$ acute, $\tilde{\mathrm{E}}=$ circumflex $)$.

4 E.g. Arumaa (1985: 319), Aitzetmüller (1991: 248). 
acute long vowel in Balto-Slavic is less straightforward today than it was some decades ago (see below $\S 5,9$ ). Third, the tacit assumption behind this argument is that the final accent of Sl. *nest $i$ is in some way unexpected and requires some type of secondary sound law to be accounted for. This is incorrect. The accentuation of the Slavic infinitive was clearly regulated by the Accentual Paradigm of the verb. ${ }^{5}$ In mobile verbs $(\mathrm{AP} c)$ the accent stood on the infinitive ending (Sl. *nesti "carry, bring", *žerti "swallow, devour"), except when it was retracted to the root or suffix in accordance with Hirt's law ("dâti "give", *bıráti "gather, take"). In immobile verbs the accent stood on the root ("sếsti "sit down", "žb̌rti "sacrifice", "pläkati "cry, weep" - all AP $a$ ), and was advanced to the next syllable in non-acute roots in accordance with Dybo's law ("jęti "take", *žęti "press, squeeze", "pbsáti “write”-all AP $b$ ). The final accent of Sl. *nesti, "žerti is confirmed by Latvian (where original ending accentuation was actually predominant, as indicated by the broken tone of bêgt "run", dzert "drink", celt "lift", aûgt "grow", jûgt "yoke", etc.). It follows that the Balto-Slavic infinitive of mobile verbs was accented on the ending as far back as we can reconstruct. It remains an open question whether the root accentuation of Slavic immobile verbs (e.g. *sě́sti) goes back to Balto-Slavic or is a Slavic innovation (contrast Latv. sêstiês).

A better argument that has been put forward in favor of loc. sg. *-têi comes from the accentuation of $i$-stem mobile nouns. If Sl. dat. sg. *kösti and loc. sg. *kosti are the regular development of PIE dat. *-téi (ei) , loc. *-tếi (:Ved. dat. -táye, loc. -tấ/-táu), this clearly favors locative origin for inf. "nesti as well. ${ }^{6}$ The problem, of course, is that it is far from certain that Sl. dat. *kösti, loc. *kosti regularly derive from PIE dat. *téi (ein), loc. *-téi. The Balto-Slavic dative of mobile nouns was always root-accented (Sl. o-st. "vôrnu, $\bar{a}$-st. *gôlvě, $u$-st. " sŷnovi = Lith. var̃nui, gálvai, súnui), whereas the locative always bore the accent on the ending (Sl. $\bar{a}$-st. " golvè̀, $u$-st. *synú, Lith. adv. namiẽ "at home" < 0 -st. * $\left.{ }^{*} \dot{i} i\right) .{ }^{7}$ Accordingly, one cannot exclude the possibility that one or more of these endings secondarily adopted the accentuation of (some of) the other stems. Nor, for that matter, can the possibility be excluded that the final accent of inf. *nest $i$ is due to factors that have nothing to do with accent position in the noun (e.g. influence of early Balto-Slavic infinitive endings that were lost before the break-up of BaltoSlavic unity).

5 The short sketch of the accentuation of the Balto-Slavic infinitive that follows is based on Villanueva Svensson (2011b: 301-306), building on earlier work by Dybo and Rasmussen.

6 So, at least in part, Stang (1942: 97), Olander (2009: 178), Jasanoff (2017: 221f.).

7 The initial accent of Sl. *ôrně (in contrast with the final accent of Lith. namiẽ) is easily explained as secondary after the initial accentuation of the whole $o$-stem singular (e.g. Stang 1966: 299). Otherwise Olander (2015: 178), Jasanoff (2017: 143). 
In short, within the current state of our knowledge it would be imprudent to try to make too much of the accentuation of the (Balto-)Slavic infinitive, and the issue (important as it is in and of itself) will be ignored in what follows. For the moment, it will be enough to note that Sl. - $t i$ is multiply ambiguous from a phonological point of view. ${ }^{8}$

\section{$3 \quad$ East Baltic}

The East Baltic facts are complex and cannot be discussed in detail here (see Endzelin 1923: 709, Zinkevičius 1966: 389). I thus prefer to simply report Stang's reconstruction (Stang 1942: 212, 1966:447-449), which can be confidently taken as standard. ${ }^{9}$ Stang reconstructs three prototypes for Lithuanian: EBl. *-ti for standard Lith. vès-ti (often apocopated, vès- $t$ ), reflexive vès-ti-s; EBl. *-tễ for the widespread Aukštaitian variant -tie, refl. -tie-s; and EBl. *-tế for Žemaitian -ti, refl. - tit-s (North-West Žemaitian -tẹ, refl. -tẹi-s). Standard Latvian ves-t, refl. vestiê-s seems to assure the East Baltic antiquity of at least * ${ }^{*} t i$ and ${ }^{*}-t e \overline{~(a l m o s t ~}$ certainly *-tế, but *-tệ cannot be excluded). The elimination of the effects of Saussure's law that the reconstruction of an acute variant * Lithuanian is certainly a problem, but not a prohibitive one (a clear parallel is provided by future $1 \mathrm{sg}$. kèp-siu, 2 sg. kèp-si for expected [and dialectally attested] kep-siù, kep-si). ${ }^{10}$ One could conceivably try to generate the different East Baltic variants from a single ending *-tẹ $>{ }^{*}-t^{\prime} i e>-t i$, refl. ${ }^{*}-t e ̣$ - $-s i>$ ${ }^{*}$-tie-si >-tie-s, with subsequent contamination of both variants." But such a scenario would require too much analogy to be credible and would have difficulties to explain the abundant (and early!) evidence for an apocopated variant $-t$.

As for the prehistory of these endings, EBl. * $-t e \underline{\text { end }}$ and $t$ ễ are standardly derived from ti-abstract loc. sg. ${ }^{*}$-tēi $i$ and dat. sg. ${ }^{*}$-tei $i\left(<\right.$ [pre-]PIE ${ }^{*}$-tein-ei $\left.i\right)$,

8 It has occasionally been suggested that Sl. -ti continues more than one ending (PIE *-tēi and ${ }^{*}$-tei, vel sim.), e.g. Arumaa (1985: 319), Hill (2016: 218), Ackermann (2017: 87). Such a possibility cannot be categorically excluded, but is not backed by any positive evidence either. See further below $\S 6$.

9 Similarly Endzelin (1923: 709), Zinkevičius (1981: 164), among others. Although a "traditional theory" of the Baltic infinitive(s) clearly emerges from the literature, it must be noted that it is often reported with caution-no doubt reflecting the complexity of the data.

10 Per Kortlandt (1982: 6), the variants with ending accentuation are found in dialects that generalize accentual mobility in the noun and are thus probably secondary.

11 E.g. Forssman (2001: 221f.). 
respectively. Here I will only observe that only the phonology of *-tei $>{ }^{*}-t e \underline{\tilde{e}}$ is completely certain; see below $\S 5,9$. Sl. - $t i$ is usually equated with the acute variant, but as stressed above ( $\S 3$ ), in reality can correspond to both. As for the third variant * $-t i$, there are two traditional accounts, both of them unattractive and with diametrically opposed chronological implications: i) an Indo-European loc. sg. *-t-i of a $t$-stem abstract; ${ }^{12}$ ii) a Baltic dat. sg. variant *-ti of a $t i$-stem abstract (beside *-tei, cf. OLith. dat. sg. ãvie ãvi, ãkmenie $\sim \tilde{a} k m e n i)$. In the first case, the grammaticalization of * $-t-i$ as an infinitive should be very old ( $t$-stems must have merged with $t i$-stems very early in Balto-Slavic) and quite unique among the Indo-European languages. ${ }^{13}$ In the second case, the grammaticaliza-

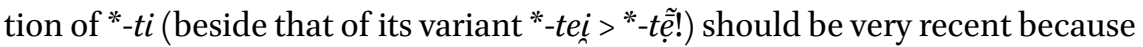
there is no reason to believe that the variation $-i e \sim-i$ in the dative singular of consonant and $i$-stems is older than Baltic (see below $\S 8$ ).

\section{West Baltic}

Though rather forcedly, one could perhaps try to derive all East Baltic infinitive variants from a single source. This is out of the question for Old Prussian, where the Catechisms present three synonymous infinitive endings: $d \bar{a}-t$ "to give", $d \bar{a}-$ twei "id.", poū-ton "to drink".

The origin of these endings has never been a matter of dispute. ${ }^{14} \mathrm{OPr}$. -ton corresponds to the supine Lith. -tu, OCS -tz and goes back to the accusative singular of a tu-stem abstract (Bl.-Sl. *-tun < PIE *-tum, cf. Lat. sup. -tum, Ved. inf. -tum). OPr. -twei is universally analyzed as the dative singular of the same formation (cf. Ved. -tave). For the moment I will only observe that PIE dat. sg. * -teu-ei should have given OPr. $\dagger$-tawei and that it is far from obvious how the expected ending was altered into pre-Prussian *-tu-ei (if this is what happened). OPr. $-t$, finally, corresponds to East Baltic * $t i$ and suffers from the same uncertainties as far as its prehistory is concerned.

12 I omit from consideration the old idea that the *-i of *-t-i was an ablaut variant of dat. sg. ${ }^{*}-t-e i$ (or of still undifferentiated dat.-loc. ${ }^{*}-t-\left.e i\right|^{*}-t-i$, vel sim.). See further below $§ 6$.

13 The only possible comparandum are the Avestan infinitives in $-t \bar{o} i /-t \bar{e}$ (< dat. sg. ${ }^{*}-t-e i{ }_{n}$ ?), on which see Kellens (1984: $347 \mathrm{f}$.).

14 E.g. Endzelin (1943: 125f.), Stang (1966: 448), among others. 
The picture that emerges from $\S 2-4$ (if the traditional approach is indeed correct) is that Baltic requires a minimum of four infinitive endings for its immediate prehistory $\left({ }^{*}-t i,{ }^{*}\right.$-te $\bar{i} i,{ }^{*}$-tein, ${ }^{*}$-tuei $)$, in addition to the supine $\left({ }^{*}\right.$-tum). From an Indo-European perspective, the existence of several infinitive endings is unremarkable and, accordingly, there is no a priori obstacle to projecting the Baltic picture into Balto-Slavic. Slavic would simply have generalized one, at most two of the infinitive endings of Balto-Slavic, in exactly the same way as Lithuanian dialects generalized one of the three endings that had survived into the prehistory of this language. Unobjectionable as this scenario may seem at first sight, there are several reasons to call it into question.

First, it is important to stress that all putative pre-Baltic infinitive endings (except for the supine) are formally problematic. Bl. *-ti (Lith. $-t(i)$, OPr. $-t)$ is altogether unclear (none of the traditional solutions is satisfactory). Bl. *-tuei (OPr. -twei) cannot directly continue PIE dat. sg. *-teu-ei. Derivation of EBl. *-tẹ (Latv. -tiê-s, Žem. -ti) from PIE (loc. sg.) * ${ }^{*}$ tẽ $i$ rests on two questionable assumptions: i) PIE long vowels and diphthongs yielded Balto-Slavic acute long vowels and diphthongs in word-final position; ii) the long diphthong * ${ }^{*} e \bar{i} i$ was monophthongized to East Baltic * $-\bar{e}$ in absolute word-final position. Both issues remain disputed at present. I cannot here devote the necessary space to discussing them, except to note that many authors would not expect PIE *-tèi to end up as EBl. ${ }^{*}-t e ̂ ́(I$, for one, would expect it to give Lith. $\dagger-t e \tilde{\imath}) \cdot{ }^{15}$ Finally, EBl. ${ }^{*}-t e \tilde{e}$ (Aukšt. $-t i e)<$ PIE (dat. sg.) *-tei is unproblematic from a phonological point of view, but requires a PIE haplology * $-e i-e i{ }_{n}{ }^{*}-e i$ that is not beyond reasonable doubt (it is supported by OCS kost-i and Lat. turr-ī, but contradicted by Ved. -aye, YAv. -aiiae-ca). We will return to these issues below.

Second, the five endings that the Baltic languages are traditionally thought to demand $\left({ }^{*}-t i,{ }^{*}\right.$-te $i,{ }_{n}{ }^{*}$-tei, ${ }^{*}$-tuei, sup. ${ }^{*}$-tum $)$ need not represent all what was there in Balto-Slavic. If the picture of multiple Balto-Slavic infinitive endings is taken seriously, there is no particular reason to stop here and the number of Balto-Slavic infinitive endings may well have been larger. A curious corollary is that the close match OCS $d a-t i$, sup. $d a-t z \approx$ Lith. dúo-ti, sup. dúo-tu

15 The development of the PIE lengthened grade in Balto-Slavic has been hotly disputed in recent years (see e.g. Villanueva Svensson 2011a, Pronk 2012, Jasanoff 2017: 83-99). Here I will only note that as far as final syllables are concerned, the majority view is that PIE long vowels and diphthongs surface as non-acute in Balto-Slavic (but see Jasanoff 2017: 89-95 for a different stance). The development of word-final long diphthongs in East Baltic is discussed in Villanueva Svensson (2016, 174-178). 
should be partly attributed to chance: each language simply generalized the same infinitive ending (or very similar endings) out of an indeterminate number of Balto-Slavic allomorphs. This is possible, but unattractive. Note that in branches that require several infinitive endings for their immediate prehistory, strong formal disagreement is the norm rather than the exception (e.g. Lat. amā-re [< $\left.{ }^{*}-s i\right]$, pass. amā-rī vs. Um. er-om "to be" [<*-om], pass. piha-fi "to be expiated"). ${ }^{16}$ Surely a more natural answer to the question of why the infinitives of Lithuanian and Old Church Slavonic look so much alike is that they continue the only infinitive ending that was there in late Balto-Slavic.

These considerations lead us to the third problem. If Balto-Slavic possessed several infinitives, what was their distribution? The Balto-Slavic infinitive was not a deradical formation, which seems to preclude a proliferation of infinitives like that of Vedic. A distribution according to voice (as in Greek or Italic) is unlikely for a branch that lost the Indo-European middle voice, probably early on. A distribution according to present stems (e.g. thematic vs. athematic) is ruled out by the fact that the Balto-Slavic infinitive was regularly made from the aorist stem. In point of fact, the clarity with which an aorist-infinitive (!) stem is reconstructed for Balto-Slavic is by itself a strong argument supporting the reconstruction of only one infinitive ending for this branch of the family. ${ }^{17}$ One could speculate that the different infinitives were correlated with different aorist stems and/or verbal classes (sigmatic aorists selecting ${ }^{*}$-te $\bar{e}$, thematic aorists *-tei, "é-statives" *-tuei, and so on), but it seems very dubious to me that late Balto-Slavic would have implemented such a complicated allomorphy, and its survival down to the dialectal period of each of the Baltic languages would be even more surprising.

In short, it is hard to imagine a formal principle that could regulate the distribution of the putative Balto-Slavic infinitives. But the distribution need not have been formal. If free variation is not assumed (clearly an unattractive assumption), one might speculate that the different infinitives of Balto-Slavic

16 But see Fortson (2012) for an attractive attempt to derive the passive infinitives of Latin and Sabellian from a single source.

17 In spite of frequent claims to the contrary, the mutual dependency between the aorist and infinitive stems in Balto-Slavic is practically exceptionless, cf. e.g. OCS žbdati/žbdaxz "wait", čisti/čisz "count, read" (: pres. židq, čstq), Lith. kir̃rpti/kir̃ po "cut", lêkti/léke "fly, run", lipti/lipo "stick to", budéti/budéjo "be awake" (: pres. ker̃pa, lêkia, lim̃̃pa, bùdi). Apparent exceptions like Lith. sver̃ti/svẽre "weigh" or bliáuti/blióve "bleat" (pres. svẽria, bliáuja) are purely apparent (Osthoff's Law). The very few cases that could imply an original independence of the two stems (e.g. Lith. dúoti "give", iñti "take" : pret. dãvé, émé; e.g. Stang 1942: 212) can be explained as secondary, cf. Villanueva Svensson (2013). At any rate, they certainly do not suffice to postulate two distinct stems for Balto-Slavic. 
were associated with some type of differences in meaning. One such case is the supine, which can be described as a positional variant of the infinitive after verbs of movement. Although strictly speaking redundant (and so finally eliminated), it survived for a considerable period of time in the languages that developed it. Its creation is easily understood in an Indo-European perspective. The large number of Vedic infinitives alone would constitute by itself sufficient grounds for the functional specialization of some of them. But while imaginable in theory, the truth remains that the older Indo-European languages did not take this path (the different infinitive endings fully agree in meaning). The historical Baltic and Slavic languages certainly lend no support to such a scenario.

A final and probably more promising approach would start by addressing the whole issue within a grammaticalization framework. For ease of exposition, I have hitherto operated with the tacit assumption that Balto-Slavic possessed a "real" infinitive, i.e., that its main usage was as complement of certain types of verbs. This is by no means certain. In addition to its complement uses, the infinitive is routinely used to express purpose in both Lithuanian and Old Church Slavonic. From a typological point of view, it is well-known that infinitives typically develop out of forms expressing purpose, which in turn typically go back to benefactive or allative case forms of action nouns (cf. Haspelmath 1989). It is perfectly possible that the Balto-Slavic "infinitive" expressed purpose alone and that it had, at best, only minimally begun to acquire "infinitive" (i.e., complement) uses. Put otherwise, it is possible that the Balto-Slavic "infinitive" was a "converb of purpose" and was thus at essentially the same stage of development as the oldest Vedic or Hittite. ${ }^{18}$ The abundance of (post-)PIE "infinitive" endings attested in the historical languages may be taken to suggest that "converbs of purpose" are more liable to be formally renewed and/or are more compatible with strong allomorphy than "real" infinitives (which are of course susceptible to several types of historical developments, but seem to be, generally speaking, more stable). If Balto-Slavic was still at the "converbs of purpose" stage, this fact alone could perhaps suffice to justify the existence of several infinitive endings in Balto-Slavic.

It is unclear to me whether this prospect actually solves the issue (in my view most of the problems discussed in this section actually remain), but the

18 Following Zehnder (2011: 629, 2016: 138) I use the term "converb of purpose" to refer to forms expressing (almost) exclusively purpose, whereas "infinitive" is reserved for typologically more evolved forms mainly used as complement (with or without additionally expressing purpose). I nevertheless keep the traditional term "infinitive" when the precise function of the reconstructed forms is irrelevant for the argument. 
grammaticalization framework entails an interesting twist. There is no reason to restrict its application to the Indo-European origins of Balto-Slavic. It is fully applicable to developments postdating the break-up of Balto-Slavic. In the reminder of this article, I will argue that (late) Balto-Slavic possessed only one infinitive $(\S 6)$ and that the other infinitives of Baltic are an exclusive coinage of this branch $(\S 7-9)$.

The first step towards a new theory of the Balto-Slavic infinitive has been recently taken by Hill (2016: 216-218). Traditionally, OCS - $t i$ has been equated with one of the East Baltic "longer" endings (Aukšt. -tie, Žem. -ti, Latv. -tiê-s). I hope to have shown that this raises severe problems and is part of a questionable approach to the Balto-Slavic infinitive. Hill's alternative runs as follows. The Balto-Slavic infinitive goes back to the PIE dat. sg. *-tei-ei (not haplologized *-tei!) of action nouns in ${ }^{*}$-ti- and makes a perfect equation with Ved. inf. -taye. In Balto-Slavic, PIE *-teiei was monophthongized to non-acute *-tī by regular sound change, which directly yields OCS, ORu. $-t i$. This Bl.-Sl. ${ }^{*}-t i \overline{\text { was }}$ shortened to *-ti in Baltic, again by regular sound change. The so obtained $\mathrm{Bl}$. ${ }^{*}$-ti directly yields Lith. $-t(i)$, Latv. $-t$, OPr. $-t$ (cf. PIE 3 sg. *-ti > OLith. ẽsti, ést, Latv. îet, OPr. ast, asti-ts).

Before discussing the phonology of this account, it may be appropriate to highlight its advantages over the traditional approach. First, it is completely straightforward from an Indo-European perspective. Second, it accounts for the only ending attested in all the Baltic and Slavic languages. Third, it directly explains the Baltic ending, which would otherwise be more difficult to account for. Fourth, the sheer weight of tradition may easily conceal the fact that the other options to join Slavic with Baltic, PIE ${ }^{*}-t e \bar{i} i$ and ${ }^{*}-t e i$, are most emphatically not better. PIE *-tē $i$, as stressed above in $\S 5$, most probably would not give East Baltic *-tẹ́ by regular sound change. PIE *-tei requires a (post-)PIE haplology *tei-ei $>{ }^{*}$-tei that seems supported by Slavic but is not supported by Baltic (as will be shown immediately below). Hill's PIE *-teiei $>\mathrm{Bl} .-\mathrm{Sl} .{ }^{*}-t \bar{\imath}>\mathrm{Bl} .{ }^{*}-t i$, if it can be shown to be fully lautgesetzlich, is certainly preferable. The phonology involved is clearly its main handicap and will thus be discussed in some detail.

The first step, the contraction PIE ${ }^{*}-e i e(i)(-)>$ Bl.-Sl. ${ }^{*}-\bar{\imath}(-)$, is a perennial controversy of Balto-Slavic historical phonology..$^{19}$ The main argument is the

19 See especially Hock (1995), with references. 
Balto-Slavic continuant of PIE iterative-causatives in *-eie/o-: OCS pres. prošq (< * pros-jo), pros-i-ši, pros-i-tż, inf. pros-i-ti, Lith. [pres. prãšo,] inf. praš-ý-ti. Other accounts have been proposed (e.g. Klingenschmitt 1978: 3-5; Kortlandt 1989), but it seems almost inconceivable to me that OCS 3 sg. pros-i-tz can be anything else than PIE 3 sg. "prok̂-éie-ti. The same holds true for the infinitive Lith. prašýti = OCS prositi (Sl. *prosíti). Since the rest of the evidence clearly indicates that the contraction product of *-eie- was non-acute *-i- (see below), the acute of Lith. inf. $-\dot{y}-t i$, Sl. * ${ }^{*} \bar{l}^{\prime}-t i\left(<\mathrm{Bl}\right.$.-Sl. $\left.{ }^{*}-\underline{-}-t \bar{c}\right)$ must have been taken from verbs with second stem in Bl.-Sl. ${ }^{*}-\bar{a}-,{ }^{*}-\bar{e}-<$ PIE ${ }^{*}-a h_{2}-{ }^{*}{ }^{*} e h_{1^{-}}$(Lith. galv-ó-ti "think", bud-é-ti "be awake"). This common analogy only reinforces the notion that the contraction *-eie- $>{ }^{*}-\overline{-}$ - was Balto-Slavic in date. Supportive evidence comes from the $i$-stem nom. pl. PIE ${ }^{*}$-ei-es > Bl.-Sl. ${ }^{*}-\bar{l}$ (OCS fem. kost-i, Lith. miñt-ys), and, above all, from the $i$-stem dative singular. The last ending has been traditionally misunderstood and thus requires some emphasis. Slavic has $-i$ as the dative singular of both consonant and $i$-stems: OCS $d z s ̌ t e r-i$, gost-i. Both are traditionally derived from PIE dat. sg. *-ei (with haplology * ${ }^{*} i-e i>_{n}{ }^{*}-e i$ in the case of the $i$-stems). In Old and dialectal Lithuanian we also find two endings, but as variants depending on dialect: ãkmen-ie $\sim \tilde{a} k m e n-i, \tilde{a} v-i e \sim \tilde{a} v-i$. Their original distribution thus cannot be recovered from the available evidence, but the equation Lith. $-i e=$ OCS $-i$ has never been in doubt. Equating Lith. $-i e$ with the $-i$ of both Slavic consonant and $i$-stems, however, has the unfortunate effect of leaving Lith. $-i$ without a proper explanation. The two traditional accounts, viz. that Lith. $-i$ derives from a zero-grade variant of the PIE dat. sg. * $-e i$ (e.g. Stang 1966: 208) and that it continues the PIE consonant-stem loc. (!) sg. ${ }^{*}-i$ (e.g. Olander 2015:145), are easily dismissed. There is no unambiguous evidence for a PIE dat. sg. "* $i$ " (whereas the evidence for non-ablauting dat. sg. ${ }^{*}-e i$ is both abundant and strong), and the transfer of a locative to the dative would be quite incredible in a language without case syncretism (there are no parallels for such a process in Lithuanian). The only way out of this conundrum is to assume that Lith. $-i e$ does not correspond to the $-i$ of both Slavic stems, but only to one of them (and Lith. $-i$ to the other). This almost automatically implies that the equations should now be posited as Lith. $-i e=$ OCS cons.-stem $-i<$ Bl.Sl. ${ }^{*}-e i<$ PIE ${ }^{*}-e i($ :Ved. $-e)$ and Lith. $-i=$ OCS $i$-stem $-i<$ Bl.-Sl. ${ }^{*}-\bar{i}<$ PIE ${ }^{*}-e i e i($ : Ved. -aye). ${ }^{20}$

20 This account implies that no haplology $i$-st. dat. sg. ${ }^{*}-e i-e i>{ }^{*}-e i$ took place in IndoEuropean. A haplologized $i$-stem dat. sg. ${ }^{*}-e i$ is only found in Italic and Celtic (Lat. turr- $\bar{t}$, Um. ocr-e, Gaul. Ucuet-e), where it is paired with a $u$-st. dat. sg. ${ }^{*}-e u>{ }^{*}$-ou (Lat. corn- $\bar{u}$, Um. trif-o, Gaul. Tapav-oov) that was probably analogical to the $i$-stem dat. sg. ${ }^{*}$-ei itself. Both processes constitute an additional argument in favor of Italo-Celtic unity. 
In my view, the conjoined evidence of the iterative-causatives in *-eie/o-, the $i$-stem nominative plural, and the $i$-stem dative singular renders the hypothesis of a Balto-Slavic contraction *-eie- ${ }^{*}{ }^{*}-\bar{l}$ - virtually certain. The counterevidence that has been traditionally quoted (OCS nom. pl. masc. trbje, pqtbje; Lith. dveji, žvejỹs, dejúoti, etc.; Stang 1966: 211) can be explained as secondary (see Hock 1995: 77 f.). At any rate, it certainly does not outweigh the evidence in favor of the contraction.

The second step, the shortening Bl.-Sl. ${ }^{*}-\bar{\imath}>\mathrm{Bl}$. ${ }^{*} i$ in unstressed position, is the really problematic side of Hill's proposal. Hill (2016: 214-222) adduces the following five pieces of evidence:

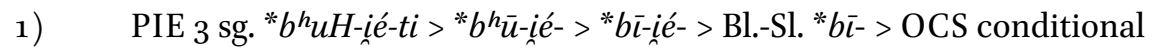
$b i$, OLith. pret. bit (i) "was" (Latv. biju), cf. Hill (2012: 19-28);

2) $i$-presents: PIE 3 sg. * ${ }^{*}$ eie-ti $>$ Bl.-Sl. ${ }^{*}-\overline{-}-t(i)(\mathrm{OCS}$ brditz "is awake") $>\mathrm{Bl}$. *-i(-t) > Lith. bùdi "id.";

3) iioo-stem nom. sg. Lith. ožỹs vs. brólis $\left(<{ }^{*}{ }^{*} \tilde{\bar{l}}\right)$; Latv. $\hat{a} z i s=$ brãlis would reflect secondary generalization of $*-\tilde{l}$;

4-5) $i$-stem dative singular; infinitive.

The first two items will not be discussed here, as both involve very marked accounts of notoriously controversial formations. No matter which position one holds (Hill's accounts are unacceptable to me, but this is not the point), they cannot be used as prima facie evidence for a non-trivial sound law. The case of Lith. ož̃ys vs. brólis is suggestive, but inconclusive because one cannot exclude the possibility that we are dealing with an exclusively Lithuanian development. ${ }^{21}$

Strong evidence for a shortening Bl.-Sl. ${ }^{*}-\bar{\imath}(s)>\mathrm{Bl}$. ${ }^{*}-i(s)$ is thus limited to the $i$-stem dative singular (on which see above) and to the infinitive itself. This is admittedly not a lot, but the arguments in favour of a phonological development PIE ${ }^{* \circ}$ eie $i>\mathrm{Bl} .-\mathrm{Sl} .{ }^{*} \bar{\iota}>\mathrm{Bl} .{ }^{*} i$ are in both cases fairly strong. There are no counterexamples. The main objection will probably be of a general nature. Long vowels were otherwise stable in Proto-Baltic (though not of course in the Baltic languages, especially in word-final position), with the result that the shortening ${ }^{*}-\bar{\imath}(s)>\mathrm{Bl} .{ }^{*}-i(s)$ looks slightly counterintuitive. The shortening could perhaps make more sense if at affected all non-acute long high vowels, but

21 The shortening ${ }^{*}-\tilde{I} s>{ }^{*}-i s$ (be it Baltic or just Lithuanian) seems contradicted by the always unaccented $i$-stem nom. pl. Lith. miñt-ys, Latv. av-is, OPr. ack-is. But this ending is very easily explained as secondary on the model of other feminine stems: (East Baltic) nom. pl. ${ }^{*}-\tilde{\tilde{a}} s,{ }^{*}-\tilde{e} s$ : acc. pl. ${ }^{*}-\bar{a} s,{ }^{*}-\bar{e} s$ (nom. pl. ${ }^{*}-\tilde{\imath} s$ : acc. pl. $\left.{ }^{*}-\hat{l} s>{ }^{*}-i s:{ }^{*}-\hat{\imath} s \rightarrow{ }^{*}-\tilde{\imath} s:{ }^{*}-\hat{\imath} s\right)$. This analogy is unproblematic regardless of the ultimate reconstruction of the Balt(o-Slav)ic accusative plural (a highly controversial issue; see most recently Kim 2019, with references). 
there are no cases of inherited non-acute ${ }^{*}-\bar{u}$ in word-final position and, accordingly, this possibility cannot be tested. Nor is this perhaps necessary. High front vowels tend to be associated with shortness cross-linguistically (cf. e.g. Jasanoff 2004: 414), and this may be enough to understand the shortening of word-final, unstressed ${ }^{*} \bar{\iota}$ alone.

The case for *-teiei $>$ Bl.-Sl. *-tī (> Bl. *-ti) stands, I believe, on firm grounds. In what follows, I will argue that all other infinitive endings that have been traditionally reconstructed for Balto-Slavic are exclusive creations of Baltic. This implies, inter alia, that inf. ${ }^{*}-t \bar{t}$, sup. ${ }^{*}$-tun is all we can reconstruct for BaltoSlavic and that, accordingly, the oldest Slavic preserves the Balto-Slavic system intact. $^{22}$

As mentioned above $(\S 4)$, the main impediment to taking OPr. -twei as a tuabstract dative singular (clearly the first option that comes to every scholar's mind) is the unexpected zero grade of the suffix. Ved. inf. -tave (< In.-Ir. *-tau$a i$, , cf. $u$-st. dat. sg. Ved. mádh-av-e, Av. -auuē), OCS $u$-stem dat. sg. syn-ovi very clearly point to PIE *-teu-e $i$ as the only form inherited by Balto-Slavic. PIE tuabstracts became unproductive in Balto-Slavic, as indicated by the extreme rarity of potential examples. ${ }^{23}$ The grammaticalization of PIE dat. sg. *-teu-ei as infinitive would thus have be very early within Balto-Slavic (if this is what happened). One could speculate that *-tu-ei somehow reflects the influence of amphikinetic $u$-stems ( ${ }^{*} n e \hat{k}-\bar{o} u-I^{*} n \hat{k} \hat{k}-u$-és, -én $i$ ), but it is hard to imagine how such a marginal type could impose its inflection on a form belonging to the robust proterokinetic $u$-stems. Such a possibility, in any case, finds no support in Indo-Iranian (Ved. inf. -tum, -toh, -tave < ${ }^{*}$-tu-m, ${ }^{*}$-teu-s, ${ }^{*}$-teu-ei are consistently "proterokinetic") or Balto-Slavic (cf. OCS gen. syn-u, dat. syn-ovi, Lith. gen. sūn-aũs). If OPr. -twei reflects some type of innovation, it must be a recent, exclusively Baltic one. This is impossible to control because the $u$-stem dative singular is not attested in Old Prussian and has been renewed in East Baltic (Lith. sún-ui has the $o$-stem ending; Latv. tirg-um is altogether analogical). It is

22 The main reason not to postulate more infinitive endings at any stage of the prehistory of Slavic is that with each additional ending the necessity to attribute the close agreement with Baltic to chance would grow exponentially. The hypothesis that the oldest Slavic simply preserves the Balto-Slavic system untouched is simpler and thus preferable.

23 The clearest case is Lith. lietùs, Latv. liêtus "id." (: líeti, -ja "pour"). See Endzelin (1923: 280), Ambrazas (1993: 49) for a handful of other candidates in Baltic. 
nevertheless hard to imagine what may have prompted a change like dat. sg. ${ }^{*}$-au-ei $\rightarrow{ }^{*}-u-e i$ and, if this happened, how it may have reached the infinitive (there were no $t u$-abstracts to serve as intermediary). A final possibility would be to posit some type of irregular truncation Bl. *-tauei $\rightarrow$ OPr. -twei, but this would be egregiously ad hoc and only highlights the fact that OPr. -twei cannot go back to PIE *-teu-ein.

In short, the traditional notion that OPr. -twei goes back to the dative singular of an action noun in *-tu-is best given up. Everything changes if we stop assuming that OPr. inf. -twei must be a formation of considerable antiquity, an approach that almost automatically excludes $t u$-stems as its immediate source. My proposal is that OPr. inf. -twei goes back to the dative singular of Baltic abstracts in *-t(u)ue.

The suffix Lith. -tuve, Latv. -tuve, OPr. -tue (with variants Lith. -tuvas, -tuvis, Latv. -tuvs, -tuva, -tuvis $)^{24}$ is best known as a suffix forming nomina instrumenti, e.g. Lith. praustùve "washstand, washbasin" (: praũsti "wash"), Latv. sę̃tuve "bast basket" (: sẽt "sow", cf. Lith. sètuvẽ “id."), OPr. coestue "brush" E 559 (:Lith. káišti "scrape", cf. Lith. kaištùvas "scraper", dial. kaištùvè). Less prominent is its use to make nomina loci (e.g. Lith. slèptùvé, Latv. slẹpptuve "hiding-place", to [Lith.] slẽpti "hide"), whereas its use in nomina agentis is rarer and clearly secondary (e.g. Lith. paleistùvis, -è "libertine", Latv. palaistuve "id.", to paléisti "set free, let go", cf. pa-si-léisti "become dissolute"). However, there is every reason to believe that the original function of this suffix was to make abstract nouns. This use is well attested in Lithuanian. In the standard language it has been specialized for ceremonies and festivities, e.g. vestùvés "wedding" (: vèsti "lead; marry"), láidotuvès "funeral" (:láidoti "bury"). But in Old and dialectal Lithuanian plain verbal abstracts without semantic restrictions are still reasonably well attested, e.g. martuvé Daukša "death; plague" (: mirrti "die"), mégintuvé Sirvydas "attempt" (: méginti "try"), dial. gyvéntuve "life; place of residence" (:gyvénti "live"), baigtùvès "ending" (: baĩgti "end"). Although not abundant, abstract nouns are also found in Latvian (e.g. loc. sg. vesstuvē "wedding", ẹstuve "food", cf. Endzelin 1923: 280) and can be posited for Old Prussian (e.g. artwes "Schiffreise", schutuan "Zwirn" Elbing, both with concretized meaning).

An interesting feature of Old Prussian is that the suffix is always monosyllabic $\langle-t u e,-t w e\rangle$. As often in Old Prussian, it is hard to say whether this is linguistically real or an imperfect rendering of /-tuve/. Lithuanian presents a monosyllabic variant -tve that in the standard language is productively used to

24 See Skardžius (1943: 385-387), Bammesberger (1973: 75-78), Ambrazas (1993: 49-51, 179f., 210f.) for more information on this suffix. 
make deadjectival abstracts (e.g. senãtve "old age", vienãtvé "solitude", to sẽnas "old", vienas "one; alone") and is thus synchronically different from the exclusively deverbative -tuve, but deverbative abstracts in -tve are attested in Old and dialectal Lithuanian, e.g. martvé Sirvydas "plague" (: mir̃ti “die"), dial. bũ stve "event" (: búti “be"). Per Bammesberger (1973: 76-78), (Lith.) -tuvé/-tve probably goes back, in the last instance, to a thematization *-tu-o- of $t u$-stem abstracts, and disyllabic *-tuu-o- to its Sievers' variant, but the Indo-European origins of this Baltic suffix (or suffixes) are immaterial for present purposes. What really matters are two facts.

First, it seems clear that (Lith.) -tuvé/-tve was a productive suffix for verbal nouns at an early stage of Baltic. It is well attested with this value, even though the overall impression is that abstracts in -tuve /-tve have been losing productivity in all Baltic languages. As noted by Bammesberger (loc. cit.), the secondary, but still Proto-Baltic specialization of -tuve to nomina instrumenti is very easy to understand starting from verbal abstracts (e.g. praũsti "wash" $\rightarrow$ praustìvé "washing" > "washing; place or instrument for washing" > "washstand, washbasin"), whereas the opposite is not the case. A final argument comes from accentuation. Like verbal abstracts in -imas, derivatives in -tuve, -tuvas, -tuvis with acute root vowel display two different types of accentuation that almost certainly depend on the original Accentual Paradigm of the verb (e.g. bliautùvé "ribald", lauktùvès "present" vs. dùmtuve "bellows", káltuvè "forge"). ${ }^{25}$ This implies a very close association of -tuve with the verbal system and thus indirectly proves its productivity as a suffix forming deverbative abstracts at an early stage of Baltic.

Second, what has been said so far makes it very reasonable that the Old Prussian infinitive OPr. -twei continues the dat. sg. * ${ }^{*} t(u) u \bar{e} e i$ of a Baltic class of deverbative abstracts in ${ }^{*}-t(u) u \bar{e}$. There is thus no necessity to try to justify a highly problematic derivation from Indo-European $t u$-abstracts. Turning back to the central topic of this article, the grammaticalization of dat. sg. ${ }^{*} t(u) u \bar{e} i$ as an infinitive ending must be an exclusively Baltic development because $\bar{e}$-stem feminines are exclusively Baltic.

As noted above ( $(3)$, the East Baltic data point to a "short" infinitive ending *-ti (Lith. $-t(i)$, Latv. $-t$ ) and to one or two "longer" one(s) (Lith. Aukšt. -tie, Žem. - $t i$,

25 Cf. Stang (1966: 472 f.), building on earlier work by Būga. 
North-West Žem. -te, Latv. refl. ves-tiê-s). The traditional notion that Lithuanian demands two East Baltic infinitives that diverged only in intonation ( ${ }^{*}$-tẹ and *-tệ) rests on very little. The bulk of the evidence points to *-tế (the ending that most naturally accounts for the Žemaitian and Latvian facts). EBl. *-tễ, on the other hand, is only supported by the absence of Saussure's Law in Aukštaitian (vès-tie $\sim$ vès-ti for †ves-ti) , but exceptions to Saussure's Law do exist (the future 1 sg. vèsiu, 2 sg. vèsi being the clearest case; see above $\S 3$ ) and, accordingly, this is not conclusive. If Lithuanian inherited only *-tẹ, the expected *ves-tie, *keptie could have been regularized to *vès-tie, *kèp-tie on the model of the many verbs in which the infinitive was not accented on the ending (*dúo-tie, *káltie, * galvá-tie, *budé-tie, *praš́-tie, etc.). This is admittedly not what Lithuanian usually did (the effects of Saussure's Law are fairly well preserved), but in the case of the infinitive the whole process would have been supported by the fact that Lithuanian had at least one more infinitive ending $\left({ }^{*}-t i\right)$ that was never accented on the ending (similarly Endzelin 1923: 710 fn. 5).

If we nevertheless assume that Aukšt. -tie really continues an East Baltic infinitive * ${ }^{*}$ ễ, three possible origins come to mind: i) a to-stem locative singular PIE *-toi > Bl.-Sl., Bl. *-tain; ii) an Indo-European $t$-stem dative singular ${ }^{*}-t$ - $e i$; iii) a Baltic ti-stem dative singular variant *-tei $\left(\sim^{*}\right.$-ti $)$. The first option is unlikely because verbal abstracts in -tas (PIE *-to-) are uncommon in Baltic. ${ }^{26}$ It is hard to evaluate the PIE $t$-stem dat. sg. * $t$ - $e i$ as a serious candidate. As noted above $(\S 3)$, if this is the origin of Aukštaitian -tie its grammaticalization as an infinitive ending must be extraordinarily ancient. The fact that its only unambiguous witness is a dialectal form that is easily explained as secondary renders this option extremely suspicious to me. The last option, the (East) Baltic dative singular variant *-tei of $t i$-stems (with ending * $-e i$ ultimately taken from the consonant stems), merits serious consideration because verbal abstracts in -tis are well established in Baltic (e.g. Lith. bütis "being, existence" $\leftarrow b u$ úti "be"). ${ }^{27}$ Unfortunately, we do not know when the consonant-stem dat sg. ${ }^{*}-e i$ began to be used in the $i$-stems nor, for that matter, what was the extension of the dative variant -tie beside inherited $-t i\left(<\mathrm{Bl} .-\mathrm{Sl} .{ }^{*}-t \bar{\imath}<\mathrm{PIE}{ }^{*}\right.$-teie $i$, see above $\left.\S 6\right)$ even in the immediate prehistory of Lithuanian. ${ }^{28}$ This immediately imposes an uncomfortable degree of uncertainty on this approach.

If Aukšt. -tie is taken at face value, a Baltic (or even only pre-Lithuanian?) dat. sg. ending *-tei is the best option that we have. Like OPr. -twei, it would

26 Cf. Skardžius (1943: 322), Bammesberger (1973: 79f.), Ambrazas (1993: 67).

27 Cf. Skardžius (1943: 326-328), Bammesberger (1973: 62-66), Ambrazas (1993: 42).

28 OPr. dat. sg. nautei (to $i$-stem nauti- "Not") seems to indicate that the confusion goes back to Proto-Baltic, but this is the only certain example and, accordingly, is not conclusive. 
be one more instance of the expansion of the morphology of the infinitive in Baltic. But, as argued above, it is also possible (and perhaps more likely) that EBl. "*-tê" is purely apparent and that all we have to account for is EBl. *-tế (beside * $-t i$, of course).

\section{Lith. dial. -tie, Latv. -tiê-s and Lithuanian abstracts in -té}

Unlike *-tễ, an East Baltic infinitive in acute *-tệ seems certain. The traditional derivation from a $t i$-stem locative singular ${ }^{*}-t e \bar{i} i$ is best given up. As stressed above $(\S 2,5)$, PIE * -tee $i$ is certainly not demanded by Slavic, whereas the phonology of PIE * $-t \bar{e} i>\mathrm{EBl} .{ }^{*}-t e \hat{e}$, which was unobjectionable some decades ago, has now become highly problematic. To be fair, one must acknowledge that the phonological issues are still unsettled and that some authors would actually expect PIE *oēi to give EBl. *oệ. I must stress, however, that the bulk of the evidence strongly suggests that PIE long diphthongs in absolute wordfinal position did not became acute and (in the case of ${ }^{*} \bar{e} i$ and ${ }^{*} \bar{a} \bar{a}$ ) were not monophthongized to East Baltic * ${ }^{*}$ - (e.g. PIE $o$-stem dat. sg. ${ }^{*}-\bar{o} i>$ pre-Lith. ${ }^{*}-u o i$ > Lith. Aukšt. -ui). I refer to Villanueva Svensson (2016: $176 \mathrm{f}$.) for the details. From a phonological point of view, the only viable source of EBl. *- $t$ ế is the locative singular of Baltic tā- or te-stem abstracts. The phonology of $\bar{a}$-stem loc. sg. PIE ${ }^{*}-a h_{2}-i>\mathrm{Bl} .-\mathrm{Sl} .{ }^{*}-a H i>{ }^{*}{ }^{*}-a i>\mathrm{Bl} .{ }^{*}-\underline{a} i>\mathrm{EBl} .{ }^{*}-\hat{e}>\mathrm{Lith} .-i e-/-i$ is discussed in Villanueva Svensson (2016). ${ }^{29}$ The feminine $\bar{e}$-stems were fully parallel to the $\bar{a}$ stems (except for the nom. sg. ${ }^{*}-\bar{a}$ vs. $\left.{ }^{*}-\tilde{e}\right)$, so we can safely reconstruct a Baltic loc. sg. * $-\underline{e}\left(>\mathrm{EBl}\right.$. ${ }^{*}-\underline{e}>$ Lith. $\left.-i e-/-i\right)$ as well. It is important to stress that there is no other possible source in the Baltic or Balto-Slavic case system.

There are two arguments that strongly favor ${ }^{*}-t \bar{e}-$ over ${ }^{*}$-tā-stems. The first one is that $t \bar{e}$-abstracts are better represented and seem to have been more productive. ${ }^{30}$ Abstracts in $-t \dot{e}$ are rare in standard Lithuanian, but they are better represented in the dialects (e.g. bégtẽ "run, running", apgaũte "deceit", to bégti "run", ap-gáuti "deceive") and, especially, in the older texts (e.g. slapte "secret", plakte "flogging", to slếpti "hide", plàkti "flog"). ${ }^{31}$ An interesting feature of té-

29 The $\bar{a}$-stem loc. sg. ${ }^{*}$-ă $i$ underlying inessive rañkoje $\left(<{ }^{*}-\bar{a} i-\underline{e n}\right)$ and adessive rañkaip $(i)\left(<{ }^{*}-\right.$ $\bar{a} i-p(r) i)$ has been formally renewed. It is not the regular continuant of PIE loc. sg. ${ }^{*}-a h_{2}-i$.

$30 \quad$ Cf. Skardžius (1943: 328f.), Bammesberger (1973: 81), Ambrazas (1993: 42-47).

31 To be sure, in Old Lithuanian abstracts in -te are only common in Sirvydas (East Aukštaitian), where they probably reflect secondary transfers of $t i$-stem abstracts in many cases, cf. Ambrazas (1993: 44f.). 
nouns is that they are also made from the second stem of derived verbs: -ote (e.g. žvejõte "fishing", to žvejóti "fish"), -autè (e.g. šienaũte "haymaking, hay harvest", to šienáuti "hay"), -uoté (važiuõté "journey", to važiúoti "travel"). ${ }^{32}$ Most examples, however, have a concretized meaning that is usually very easy to understand as having developed from original plain verbal nouns, e.g. duotẽ "tribute" (: dúoti "give"), iškir̃pte "décolleté" (: iš-kir̃pti "cut out"), gaũbte "cloak" (: gaũbti "cover, put on"), kapõte "hoe" (: kapóti "chop, hew"), etc. Here belong the few nouns in *-tē in Latvian and Old Prussian, which, on the other hand, include some remarkable word equations among the Baltic languages, e.g. Lith. var̃pste = Latv. vàrrpste "spindle" (: [Lith.] ver̃pti "spin"), Lith. rý( $k$ šste = Latv. riste $2 /$ rĩkste = OPr. riste "rod, switch" (: rišsti "bind, tie"), Lith. grĩžte "straw tie" = Latv. grizte "braid, plait, spin" = OPr. greanste "withy" (: gręžzti "bore; wring; turn").

There can thus be no doubt that Baltic possessed a class of nomina actionis in *-te. The case of this suffix is similar to ${ }^{*}-t(u) v \bar{e}$ in that it evidently ceased to be productive at some point, with the difference that * $t \bar{e}$ did not experience any secondary productivity with some specialized meaning (like Lith. -tuve for nomina instrumenti).

I find it unnecessary to give a detailed report of nomina actionis in *-tā. ${ }^{33}$ They are less well established than nomina actionis in *-te (which are not terribly prominent either), and the few more salient subtypes that we have (1. deverbatives with o-grade, e.g. Lith. naštà "burden", to nèšti "carry, bear"; 2. deadjectives in -ata, e.g. sveikatà "health", to sveĩkas "healthy") were not particularly favorable to the inclusion of this suffix in the verbal system.

A second reason to favor *-té-stems over *-tā-stems comes from a verb form that has hitherto played no role in the discussion: the Lithuanian "second infinitive" (Lith. büdinỹs) in -te. The term "second infinitive" is a misnomer. The büdinỹs is a manner adverb derived from the infinitive stem that intensifies the meaning of the main verb, e.g. bégte/bégtè bégti "run as fast as possible", šauktè šaũkti "shout at the top of one's lungs", válgyte válgyti "eat a lot", kartóte kartóti(s) "repeat (oneself) a lot", etc. Since the büdinys can be made, in principle, from every verb of the language (and must thus be described as part of the verb system, even if a very peripheral one), "converb of manner" would be a more appropriate term. Beside -te, a variant in -tinai (an adverbial derivative of the participle of necessity) is quite widespread: bègtinaĩ, kartótinai, etc. Other optional variants are attested in the dialects (bégtinõ, bégtinõs, bégčià, bégčiomis, bégomis), all of them historically transparent as well (cf. Zinkevičius

32 Resegmented -uote is the only suffix that remains productive in the modern language, e.g. treniruõte "training", grupuôté "group", etc.

33 Cf. Skardžius (1943: 323), Bammesberger (1973: 79f.), Ambrazas (1993: 67). 
1966: 389 f.). In Latvian the plain infinitive can be used to express the same function, cf. Endzelin (1923: 776f.). It is impossible to tell which form stands behind Latv. inf. $-t$ in this construction, but a shortening of pre-Latv. * $-t i<$ EBl. * ${ }^{*} t e ̂ n$ (: Lith. -te) is a distinct possibility (as duly noted by Endzelin 1923: 709 fn. 1). This perspective would help explain the abundance of Latvian verbal adverbs expressing meanings very close to those of the Lithuanian büdinỹs (Latv. -u, -us, $-\check{s} u$, -šus, -in, -tin), virtually all of them with a plausible inner-Latvian explanation (cf. Endzelin 1923: 223-225).

The origin of the Lithuanian büdinys in -te (East Aukštaitian - $t i$ ) is perfectly clear. It goes back to the instr. sg. * ${ }^{*} t \bar{n}$ of verbal abstracts in *-tē-. This confirms that verbal nouns in *-te- had a wider distribution in the prehistory of Baltic than the meager relics of the historical languages would suggest. It also indirectly confirms that the East Baltic infinitive *-tế goes back to the loc. sg. *-tei of an exclusively Baltic class of verbal nouns in *-te-. The ultimate origin of this suffix is immaterial for present purposes and will not be treated in detail here. Verbal nouns in ${ }^{*}-t \bar{e}$ - are usually explained as transfers to the productive class of $\bar{e}$-stem feminines of either nomina actionis in *-tā- or nomina actionis in *-ti(references in Ambrazas 1993: 46). Here I shall only note that I do not regard these two accounts as mutually exclusive.

The main result of the preceding sections is that the morphology of the infinitive experienced a period of expansion in Baltic. Baltic inherited from BaltoSlavic a very simple system consisting of infinitive ${ }^{*}-t i<{ }^{*}-t \bar{\imath}(<$ PIE $t i$-stem dat. sg. *-teiei) and supine ${ }^{*}$-tun (<PIE tu-stem acc. sg. *-tum). At some point, Baltic added some new infinitives. OPr. -twei continues the dative singular of an abstract noun in *-t(u)ue (Lith. -tuvè). Latv. refl. -tiê-s, Žem. -ti (and Aukšt. -tie?) continue the locative singular of an abstract noun in ${ }^{*}-t \bar{e}$ (Lith. $\left.-t \dot{e}\right): \mathrm{Bl} .{ }^{*}-t e \underline{i}>$ EBl. * - tẹ́. The instrumental singular of this formation gave rise to a "converb of manner" (Lith. - te, Aukšt. - $t i$, perhaps Latv. $-t$ ). The existence of one more infinitive in Aukšt. -tie is dubious. It would be the only infinitive ending derived from a suffix of Indo-European antiquity ( ${ }^{*}$-ti-), but the precise form it would have to continue (dat. sg. *-tei) was, once again, specifically Baltic.

This scenario immediately raises several questions concerning the nature, date, and range of the expansion of the Baltic infinitive. I will take up the last question first. As noted above $(\S 5)$, once one begins operating with a multiplicity of infinitives in prehistory it is almost impossible to know where to stop. In principle, it could be the case that Baltic possessed more infinitives than 
the two or three attested in each of the Baltic languages. It is also conceivable that some of them managed to survive into the historical period. I give a list of potential candidates known to me: ${ }^{34}$

i) OPr. $\langle$ poyte $\rangle$ "to drink", $\langle$ doyte $\rangle$ "to give" in the Basel Epigram. As often with Prussian orthography, it is hard to say what $\langle-t e\rangle$ stands for. ${ }^{35}$

ii) Lith. dial. -ty in two small, non-contiguous areas, cf. Zinkevičius (1966: 389 ).

iii) Lith. dial. -ta in Vidiškai (East Aukštaitian, near Ukmergẽs), at least after baĩgti "end, finish", cf. Zinkevičius (1966: 389).

iv) Endzelin (1951: 918) mentions a few infinitives in -ta (e.g. ẹsta "eat", dzerta "drink") from Neretas, Latvia, which he derives from *-te.

v) Finally, it is interesting to note that Endzelin (1923: 280) qualified some of the instances of verbal abstracts in Lith. -tuve, Latv. -tuve as "infinitival" in usage.

It is very hard to evaluate this material as potential witnesses of Proto-Baltic infinitives other than the ones we have already met—or, for that matter, of the presence of *tei ${ }^{*}$-tei in West Baltic and *-tuei in East Baltic. To exemplify with Lith. dial. $-t a$, this could indeed be a precious relic not yet engulfed by $-t(i)$ or -tie, but its historical interpretation is not self-evident (though see below for one possibility) and, generally speaking, material of such an isolated dialectal status is more likely to represent an idiosyncratic local innovation than a precious archaism. Similar considerations apply to the other endings.

The range of the expansion of the infinitive in Baltic must thus remain an open question. We find ourselves on more favorable ground to determine the date of the expansion. All the arguments one can adduce suggest that the expansion took place in Proto-Baltic, not in the separate prehistory of the individual Baltic languages. First, ${ }^{*}-t(u) u \bar{e}$ and ${ }^{*}-t \bar{e}$ are either very moderately productive in the historical languages or display no productivity at all. The grammaticalization of infinitives out of dat. sg. ${ }^{*}-t(u) u \bar{e} i$ or loc. sg. " $-t e \underline{i}$ thus cannot be recent. Second, the loc. sg. * $\underline{\text { e }} \underline{i}$ (> EBl. * $\left.{ }^{*}-\hat{e}\right)$ of $\bar{e}$-feminines was renewed as ${ }^{*}-\bar{e} i$ in the prehistory of (East) Baltic. Since loc. sg. ${ }^{*}-\bar{e} i$ itself is only seen in the postpositional cases (inessive žêmeeje $<{ }^{*}$-ề-en, adessive biteip $<{ }^{*}$-èi-p $\left.p(r) i\right)$, the grammaticalization of at least the loc. sg. * -tei must have taken place at an early stage of Proto-Baltic. Third, because of the nature of our texts it is practically

34 Here I am only concerned with potentially old, Proto-Baltic material. I thus exclude from consideration demonstrably recent variants (see e.g. Zinkevičius 1981: 163, Endzelin 1923: 225).

35 Note also meicte/moicte "sleep" (Grunau), if not 3rd person present (cf. OLith. miegóti, miegmi “id."). 
impossible to know what was the distribution of the Old Prussian infinitives, ${ }^{36}$ but in East Baltic the tendency clearly was for the allomorphic complexity of the infinitive to decrease (Lithuanian and Latvian dialects present just one, at best two infinitive endings).

In short, the process of expansion almost certainly took place already in Proto-Baltic. This leads us to the last question(s): what happened and why did it happen? These are, needless to say, the most difficult questions of all, and the suggestions that follow should be understood as tentative. I can see two options.

The first "account" of the expansion of the infinitive in Baltic would state, in essence, that there is nothing particularly remarkable to it. Let us recall, first of all, that the Balto-Slavic infinitive $\left({ }^{*}-t \bar{\imath}>\mathrm{Bl} .{ }^{*}\right.$-ti) and supine $\left({ }^{*}\right.$-tun) were perfectly well preserved down to the historical languages. This indicates that we are not dealing with the usual picture of an innovated ending replacing an older one after a period of competition (as, say, in the English to-infinitive or the German $z u$-infinitive). Rather, it seems that Baltic inherited a perfectly balanced system and, for some reason, decided to complicate it by introducing a number of unnecessary allomorphs. This does not make much sense if what Baltic inherited was an "infinitive", but it may be understandable if what Baltic inherited was a "converb of purpose". To resume the discussion in $\S 5$, the Indo-European languages present an impressive array of different "infinitives". Many of them are synchronically unanalyzable and must thus have been grammaticalized at an early date (Gk. $-\mu \varepsilon v,-\nu \alpha \mathrm{l},-\sigma \theta \alpha \mathrm{l}$ etc.). At least one "infinitive" (that of Ved. -dhyai, Um. $-f i$ and Toch. B -tsi) shows all the signs of going back to the parent language itself. Fortson (2013) plausibly reconstructs ${ }^{*}-d^{h} i \bar{e} i$, which would be unanalyzable already in Indo-European and thus quite old within it. PIE antiquity can be advocated for other endings as well (e.g. Ved. -sáni Gk. $\left.-\varepsilon l \nu<{ }^{*}-e_{-}{ }^{h} e n\right)$, but an extended treatment is unnecessary here. The point to stress is that the evidence points to two apparently incompatible generalizations: 1. PIE had no "infinitive" because the languages differ too wildly; 2. PIE had one or more "infinitives" because some of the endings cohere very well. But the paradox is only apparent. I refer to Keydana's discussion (2013: 37-47), and limit myself to highlighting his conclusion for Vedic: "Damit dürfte jeder Spekulation über die Rezenz des Infinitivs im Altindischen der Boden entzogen sein. Die Kategorie ist alt (...). Was wir vor Augen haben, ist vielmehr eine erhebliche Erweiterung des morphologischen Arsenals zur Markierung einer

$36 \quad$ Kortlandt (199o) tries to establish a functional difference between the Prussian infinitive endings, but the evidence is inconclusive. See the discussion in Schmalstieg (2000: 213215). 
bereits existenten Kategorie" (loc. cit., 46; emphasis mine).Zehnder's (2011: 629, 2016: 138) rechristening of the Vedic "infinitives" as "converbs of purpose", I believe, goes well beyond a terminological improvement. It effectively clarifies matters in a way that the term "infinitive" irremediably blurred. The basic lesson to be learned from the Indo-European languages is that "converbs of purpose" are easily renewed, whereas real "infinitives" are probably more stable.

Turning back to Balto-Slavic, the fact that all historical languages have an infinitive from the oldest records is not a conclusive argument for reconstructing a "real" infinitive for Balto-Slavic. The functional agreement in the use of the infinitive in both branches is easily understood as typological in nature. The alternative view that Balto-Slavic had a converb of purpose and that this was kept for a considerable period of time in Baltic is supported by at least two arguments. The first one is the very fact that the infinitive is routinely used to express purpose in Lithuanian and Old Church Slavonic. This is needless to say not probative. The second and stronger argument is the construction dativus cum infinitivo, which is still alive in modern Lithuanian (e.g. atvežiau karčiu $_{\text {tvorai }}$ [Dat.] $_{\text {tverti }}$ [nf.] "I brought poles to fix the fence"), and has left clear traces in Slavic as well, cf. Ambrazas (2006: 317-326). This construction is also found in Vedic (cf. Keydana 2013: 123-143) and Hittite (cf. Melchert 2012). It is generally agreed that it arose through syntactic reanalysis of two originally independent final adjuncts. It is probably not a coincidence that the dativus cum infinitivo construction seems to be proper to those languages in which converbs of purpose have at best barely begun to acquire infinitive usages. This suggests that the grammaticalization of the infinitive took place independently (and recently) in Baltic and Slavic. A third argument would be the very creation of new "infinitives" in Baltic, which would be surprising if Baltic had inherited a true "infinitive" from Balto-Slavic.

One could thus say that the expansion of the infinitive in Baltic was a consequence of the general conservatism of this branch, which preserved the IndoEuropean case system, made widespread use of verbal abstracts, and still had converbs of purpose. It would be ultimately comparable to the case of Vedic, and equally unremarkable. I do not exclude that this scenario is indeed the whole story, but it is susceptible to several types of criticism. First, we do not really know whether Balto-Slavic and Baltic had "converbs of purpose" and not yet fully developed "infinitives". The system we can reconstruct for (late) Balto-Slavic ("inf." *-ti, sup. *-tun) probably favors a real infinitive. In this case, the dativus cum infinitivo construction would be a syntactic archaism of BaltoSlavic date that modern Lithuanian simply managed to preserve. Second, the verbal system of Baltic was certainly less favorable to acquiring new "infinitive" allomorphs that that of Vedic (as detailed above, §5). Third, OPr. -twei $(<\mathrm{Bl}$. 
dat. *-t(u)ueiei) and Aukšt. -tie (if from Bl. dat. *-tei $)$ would be typologically unremarkable, but Žem. -ti, Latv. -tiêes (<Bl. loc. *-tei ) probably not. Infinitives of locative origin are certainly attested in the old Indo-European languages (Ved. -sáni, Gk. $-\mu \varepsilon v,-\varepsilon \imath \nu\left[<{ }^{*}-e-h e n<{ }^{*}-e-s e n\right]$, Lat. $\left.-r e\left[<{ }^{*}-s-i\right]\right)$, but they are distinctly rare, must have been grammaticalized very early (except for Lat. - $r e$ ), and constitute a problem from a typological point of view (infinitives regularly evolve from cases with allative or benefactive semantics, not from locatives). The issue cannot be discussed at length here. Whatever factor made the creation of Ved. -sáni or Gk. $-\mu \varepsilon v$ acceptable at an early date (via the "locative of the achieved goal"?), it was probably not present in Proto-Baltic (where as far as we can tell the locative was just a locative). Note, finally, that this approach cannot include in the same process the creation of a "converb of manner" (Bl. *-tén > Lith. -te), which would have to be an entirely independent development (although this does not seem a particularly damaging assumption).

I do not know whether these objections render the scenario sketched so far an utterly problematic one. Probably its main handicap is that it forces us to operate with a strange to-and-fro evolution: 1. (Late) Balto-Slavic had eliminated whatever allomorphy it may have inherited and possessed just one "infinitive" and a supine. 2. Proto-Baltic then decided to complicate matters and created several new "infinitive" endings. 3. But the Baltic dialects then decided to return to the Balto-Slavic state of affairs, with one "infinitive" and a supine. 4. The last stage was to keep only one "infinitive" by dropping the supine. All this does not seem very logical unless one can motivate step 2 in some way or, at least, provide a parallel. Such a parallel is indeed available in the case system: 1. Baltic inherited from Balto-Slavic a notoriously conservative case system. 2. This was complicated in Baltic through the addition of several postpositional local cases. 3. These were eventually lost and modern Lithuanian has essentially returned to its Balto-Slavic point of departure.

This parallel immediately hints at a second possible explanation for the expansion of the infinitive in Baltic. The creation of a new set of postpositional cases has often been attributed to Uralic influence. Another well-known possible outcome of Uralic influence is the loss of number distinction in the third person verb ending. An extended treatment of prehistoric contacts between Balt(o-Slav)ic and Uralic would be out of place here (and would vastly exceed my competence), see e.g. Thomason \& Kaufman (1988: 238-251) or the essays collected in Junttila (2015). For present purposes, it is enough to note that there are good reasons to take the possibility of structural influence of Uralic on Baltic very seriously.

Coming back to our main topic, the Uralic languages are characterized by complex systems of converbs and other non-finite forms, see Ylikoski (2003: 
203-205). Converbs not expressing purpose or not otherwise compatible with an infinitive are irrelevant here, but it is probably worth noting that this approach has the additional advantage of including in the same process the creation of a "converb of manner" in Baltic (a rarity among the Indo-European languages of Europe, cf. Nedjalkov 1998: 443). As for the infinitive, its expansion in Baltic may have taken place in different ways. One of them is by reinforcing the difference between directional-purposives (Mary went to take photos of Sabina) and (non-directional) purposives (Mary bought a camera in order to take photos of Sabina). These are expressed with different forms in Finnish, but the reinforcement of the non-directional purposive meaning of infinitives is a recurrent development (cf. German um zu, Spanish para, Russian čtoby, etc.; see Ylikoski 2003: 207f.). If this is what happened in Baltic, it certainly does not require Uralic interference. Of more interest for present purposes is Ylikoski's (2003: 209-214) subsequent discussion of the infinitive, especially the following two observations: “(...) this suggests that there underlies a crosslinguistically valid, albeit quite abstract, syntactic-semantic concept of infinitive, which in turn is realized in individual languages either as a single form or several alloforms" (op. cit., 209), “(...) as complements, infinitives can be said to express various 'modalities,' but actually the semantic functions of infinitives are largely determined by their main verbs" (op. cit., 210). The supine in Balto-Slavic and Italic is a clear case of an infinitive "alloform" specialized in one of the main "modalities" of the infinitive, but it is practically the only case among the old Indo-European languages. When a language has several infinitives, these are distributed according to formal or lexical criteria, and the different "infinitives" do not express different "meanings" or "modalities". However, systems of several infinitives and converbs expressing different infinitive "modalities" are normal in Uralic languages, where they typically derive from oblique case endings of action nominals (see Ylikoski, loc. cit., for documentation). It does not take much imagination to envisage a situation in which contact with Uralic caused Proto-Baltic to develop a system of several functionally specialized "infinitive" allomorphs. The same situation led to the loss of number distinctions in the 3 rd person and to the addition of several postpositional local cases. Interestingly, both the infinitive and the local case systems were later simplified to a "normal" Indo-European system.

Probably the main handicap of this scenario is that it cannot be specified or controlled in any independent way. Needless to say, this is often the case when dealing with language contacts in distant prehistory. One of the few criteria that renders such a hypothesis highly probable is the existence of a large number of clearly recognizable loanwords. In this case, the large number of Baltic borrowings in the Baltic Finnic languages clearly demonstrate that extensive contacts 
took place, but borrowings were rather one-sided from Baltic to Uralic. This surely does not preclude a subtler Uralic influence on the grammatical structure of Proto-Baltic, but the scarcity of Uralic borrowings in Baltic will always impose some reservations on the idea that, say, the absence of number distinction in the third person ending of the Baltic verb is due to Uralic influence (though this remains possible). As for the Baltic infinitive, it is unfortunately impossible to tell whether *-ti, ${ }^{*}-t(u) u \bar{e} i$ and *-tei had different "meanings" or "modalities" in Proto-Baltic, something that would slightly support the idea of a Uralic model. Functional specialization is certain for the supine *-tun, where it was inherited from Balto-Slavic, but nothing in the historical record suggests that ${ }^{*}-t i$ and ${ }^{*}$-tei diverged in meaning. Curiously, the most promising case is at the same time the most insecure. If Lith. dial. -ta after baigti "end, finish" (and Latv. dial. -ta? see above) represents an archaism, its most natural explanation is a genitive singular (pronounced [- $\mathrm{e}]$ in this dialect; standard Lith. $-o$ ) of Baltic nouns in *-tas (PIE *-to-). Baltic abstracts in *-tas present the same profile as abstracts in *-tā and, like these, are not particularly common. ${ }^{37}$ If we nevertheless assume that they were slightly more common in Proto-Baltic and that a case ending of abstracts in *-tas was grammaticalized as an infinitive, the restriction of Lith. dial. - $t a$ after baĩgti is strongly reminiscent of similar facts in Uralic languages, where verbs like "cease", "refuse", "forbid" take a complement with ablative meaning that in several languages has evolved into an infinitive, cf. Ylikoski (2003: 212 f.). But, as noted above, it is practically impossible to be sure that Lith. dial. $-t a$ is an archaism and not a peculiar innovation of a very limited area.

To sum up, in this section I have presented two accounts of the expansion of the infinitive in Baltic, one operating with the notion of Baltic archaism, the other with Uralic interference. These two accounts need not exclude each other. The whole process would make excellent sense if Uralic influence took place when the putative Balto-Slavic "converb of purpose" was acquiring "infinitive" (i.e., complement) uses. But it is probably unwise to try to be too specific. The very notion of an expansion of the infinitive in Baltic depends on formal arguments and is independent of our capacity to explain why it happened. Note, finally, that all new infinitives begin with ${ }^{*}-t^{\circ}$. This suggests that a certain family resemblance to inherited inf. ${ }^{*}$-ti, sup. ${ }^{*}$-tun may have been an additional factor. 
The results of this study are easily summarized. The reconstruction of the BaltoSlavic and Baltic infinitive system has traditionally depended on two slightly incompatible assumptions: i) the systems of (e.g.) Lithuanian and Old Church Slavic resemble so much each other that they must derive from a common Balto-Slavic prototype; ii) the Baltic evidence requires several infinitive endings. The first part of this article $\left(\S_{1-5}\right)$ is devoted to highlighting the problems raised by the traditional approach to the Balto-Slavic infinitive.

The second part of the article $(\S 6-10)$ presents a new theory of the BaltoSlavic and Baltic infinitive. Balto-Slavic possessed just one infinitive, which is preserved in all languages (PIE $t i$-abstract dat. sg. ${ }^{*}$-teiei $>$ Bl.-Sl. ${ }^{*}-t \bar{\imath}>\mathrm{OCS}$, ORu. $-t i$; Bl. *-ti $>$ Lith. $-t(i)$, Latv. $-t$, OPr. $-t)$, in addition to a supine *-tun (<PIE *-tum), also continued in all languages (OCS, ORu. -tz; Lith. -tu, Latv. -tu, OPr. -ton). The phonology behind the Balto-Slavic infinitive has become clear very recently $(\S 6)$. All other infinitive endings were created in Proto-Baltic $(\S 7-9)$. OPr. -twei continues the dative singular * $-t(u) u \bar{e} i$ of abstract nouns in * $-t(u) u \bar{e}$ (Lith. -tuvè). Latv. refl. -tiê-s, Žem. - $t i<\mathrm{EBl}$. *-tẹ continue the locative singular *-tei of abstract nouns in *-té (Lith. -tè). The instrumental singular * $-t e \underline{n}$ gave rise to a "converb of manner" (Lith. -te, Aukšt. -ti, perhaps Latv. -t). Aukšt. - tie, if it really continues EBl. * $-t e \bar{e}$, continues an exclusively Baltic dative singular ${ }^{*}-t e i$ of abstract nouns in *-ti-. It is practically impossible to ascertain whether still more infinitives were created in Baltic. Two possible explanations of the expansion of the infinitive in Baltic are discussed ( $(10)$, one assuming an archaic, Vedic-like functional profile of the Baltic and Balto-Slavic infinitive, the other operating with Uralic influence.

\section{References}

Ackermann, Katsiaryna. 2017. Towards the prosodic structure of infinitive formations in Baltic and Slavic and its diachronic implications. Indogermanische Forschungen 122, 83-104.

Aitzetmüller, Rudolf. 1991. Altbulgarische Grammatik als Einführung in die slavische Sprachwissenschaft. 2., verbesserte und erweiterte Auflage. Freiburg: Weiher.

Ambrazas, Saukius. 1993. Daiktavardžiu darybos raida. Vilnius: Mokslo ir enciklopedijų leidykla.

Ambrazas, Vytautas. 2006. Lietuviu kalbos istorinè sintaksė. Vilnius: Lietuvių kalbos institutas.

Arumaa, Peeter. 1985. Urslavische Grammatik. III. Band: Formenlehre. Heidelberg: Carl Winter. 
Bammesberger, Alfred. 1973. Abstraktbildungen in den baltischen Sprachen. Göttingen: Vandenhoeck \& Ruprecht.

Endzelin, Jānis. 1923. Lettische Grammatik. Heidelberg: Winter.

Endzelin, Jānis. 1943. Senprūšu valoda. Riga: Universitātes apgāds.

Endzelin, Jānis. 1951. Latviešu valodas gramatika. Riga: Latvijas valsts izdevniecība.

Forssman, Berthold. 2001. Lettische Grammatik. Dettelbach: J.H. Röll.

Fortson, Benjamin W. 2012. Latin -rier and its Indo-Iranian congeners. Indogermanische Forschungen 117, 75-118.

Fortson, Benjamin W. 2013. Pre-Italic *-dhie $\left({ }^{*}-d h i e h_{1}\right)$ versus Pre-Indo-Iranian *-dhiōo $i$ : bridging the gap. In: Adam I. Cooper, Jeremy Rau \& Michael Weiss (eds.), Multi Nominis Grammaticus. Studies in Classical and Indo-European Linguistics in Honor of Alan J. Nussbaum on the Occasion of his Sixty-Fifth Birthday, 50-6o. Ann Arbor-New York: Beech Stave Press.

Haspelmath, Martin. 1989. From purposive to infinitive - a universal path of grammaticalization. Folia Linguistica Historica 10, 287-310.

Hill, Eugen. 2012. Die Entwicklung von ${ }^{*} u$ vor unsilbischem ${ }^{*} i$ in den indogermanischen Sprachen Nord- und Mitteleuropas: die Stammsuppletion bei $u$-adjektiven und das Präsens von "sein". North-Western European Language Evolution 64/65, 536.

Hill, Eugen. 2016. Phonological evidence for a Proto-Baltic stage in the evolution of East and West Baltic. International Journal of Diachronic Linguistics and Linguistic Reconstruction $13,205^{-232 .}$

Hock, Wolfgang. 1995. Die slavischen $i$-Verben. In: Heinrich Hettrich, Wolfgang Hock, Peter-Arnold Mumm \& Norbert Oettinger (eds.), Verba et Structurae. Festschrift für Klaus Strunk zum 65. Geburtstag, 73-89. Innsbruck: Institut für Sprachwissenschaft der Universität Innsbruck.

Jasanoff, Jay. 2004. Plus ça change ...: Lachmann's Law in Latin. In: J.H.W. Penney (ed.), Indo-European Perspectives: Studies in Honour of Anna Morpurgo Davies, 405-416. Oxford-New York: Oxford University Press.

Jasanoff, Jay. 2017. The Prehistory of Balto-Slavic Accent. Leiden-Boston: Brill.

Junttila, Santeri (ed.). 2015. Contacts between the Baltic and Finnic Languages. Helsinki: Suomalais-Ugrilainen Seura.

Kellens, Jean. 1984. Le verbe avestique. Wiesbaden: Reichert.

Keydana, Götz. 2013. Infinitive im Rgveda: Formen, Funktion, Diachronie. Leiden-Boston: Brill.

Kim, Ronald. 2019. North Slavic -ě vs. South Slavic -ę: a problem of forward reconstruction. Journal of Slavic Linguistics 27, 1-26.

Klingenschmitt, Gert. 1978. Zum Ablaut des indogermanischen Kausativs. Zeitschrift für vergleichende Sprachforschung 92, 1-13.

Kortlandt, Frederik. 1982. Innovations which betray archaisms. Baltistica 18, 4-9. 
Kortlandt, Frederik. 1989. Lithuanian statýti and related formations. Baltistica 25, 104112.

Kortlandt, Frederik. 199o. Old Prussian infinitives in -ton and -twei. In: Baiba MetuzāleKangere \& Helge D. Rinholm (eds.), Symposium Balticum. A Festschrift to Honour Professor Velta Rūk,e-Dravina, 213-218. Hamburg: Helmut Buske.

Matasović, Ranko. 2008. Poredbenopovijesna gramatika hrvatskogajezika. Zagreb: Matica hrvatska.

Meillet, Antoine. 1934. Le slave commun. Seconde édition revue et augmentée avec le concours de A. Vaillant. Paris: Champion.

Melchert, Craig. 2012. Dative-locative objects of infinitives in Anatolian. Historische Sprachforschung 125, 242-247.

Nedjalkov, Igor' V. 1998. Converbs in the languages of Europe. In: Johan van der Auwera \& Dónall P. Ó Baoill (eds.), Adverbial Constructions in the Languages of Europe, 421-455. Berlin: de Gruyter.

Olander, Thomas. 2009. Balto-Slavic Accentual Mobility. Berlin-New York: de Gruyter.

Olander, Thomas. 2015. Proto-Slavic Inflectional Morphology. A Comparative Handbook. Leiden-Boston: Brill.

Pronk, Tijmen. 2012. Proto-Indo-European long vowels and Balto-Slavic accentuation. Baltistica 47, 205-247.

Schmalstieg, William R. 200o. The Historical Morphology of the Baltic Verb. Washington DC: Institute for the Study of Man.

Skardžius Pranas. 1943. Lietuvių kalbos žodžiu daryba. Vilnius: Lietuvos mokslo akademija.

Stang, Christian S. 1942. Das slavische und baltische Verbum. Oslo: Dybwad.

Stang, Christian S. 1957. Slavonic Accentuation. Oslo: Universitetsforlaget.

Stang, Christian S. 1966. Vergleichende Grammatik der baltischen Sprachen. OsloBergen-Tromsö: Universitetsforlaget.

Thomason, Sarah Grey \& Terrence Kaufman. 1988. Language Contact, Creolization, and Genetic Linguistics. Berkeley-Los Angeles-London: University of California Press.

Vaillant, André. 1966. Grammaire comparée des langues slaves. Tome III: Le verbe. Paris: Klincksieck.

Villanueva Svensson, Miguel. 2011a. Indo-European long vowels in Balto-Slavic. Baltistica $46,5^{-3} 8$.

Villanueva Svensson, Miguel. 2011b. The accentuation of the infinitive type Latv. kaitt, Sl. *költi and the development of Indo-European molo-presents in Balto-Slavic. In: Vytautas Rinkevičius (ed.), Proceedings of the 6th International Workshop on BaltoSlavic Accentology (= Baltistica 7 Priedas), 301-326. Vilnius: Vilniaus universiteto leidykla.

Villanueva Svensson, Miguel. 2013. Two Baltic irregular preterites: Lith. dãve "gave", éme "took". Baltistica 48, 225-244. 
Villanueva Svensson, Miguel. 2016. Lith. anksti, arti, toli and Baltic and Slavic Auslautgesetze. Scando-Slavica 62, 16o-182.

Ylikoski, Jussi. 2003. Defining non-finites: action nominals, converbs and infinitives. SKYJournal of Linguistics 16, $185^{-237 .}$

Zehnder, Thomas. 2011. Zur Funktion der Infinitive im Veda. In: Thomas Krisch \& Thomas Lindner (eds.), Indogermanistik und Linguistik im Dialog. Akten der XIII. Fachtagung der Indogermanischen Gesellschaft vom 21. bis 27. September 2008 in Salzburg, 622-631. Wiesbaden: Reichert.

Zehnder, Thomas. 2016. Review of Keydana 2013. Journal of South Asian Languages and Linguistics 3, 133-139.

Zinkevičius, Zigmas. 1966. Lietuvių dialektologija. Vilnius: Mintis.

Zinkevičius, Zigmas. 1981. Lietuvių kalbos istorinė gramatika. Vol. 2. Vilnius: Mokslas. 